\title{
A Comparative Study of Isabel Allende "Ines of My Soul" and Gabriel Garcia Marquez "Love in the Time of Cholera" from the View Point of Features of Magic Realism
}

\author{
Fatemeh Azizmohammadi ${ }^{1} \&$ Atieh Rafati ${ }^{1}$ \\ ${ }^{1}$ School of Humanity and Social Sciences, Islamic Azad University, Arak, Iran \\ Correspondence: Atieh Rafati, School of Humanity and Social Science, Islamic Azad University, Arak, Iran. \\ E-mail: rafatiatieh@gmail.com
}

Received: December 12, 2017 Accepted: January 25, 2018 Online Published: February 8, 2018

doi:10.5539/ells.v8n1p57ＵRL: https://doi.org/10.5539/ells.v8n1p57

\begin{abstract}
This tentative study suggests Isabel Allende "Ines of my soul" and Gabriel Garcia Marquez "Love in the Time of Cholera" from magic realism point of view. Magic Realism is a Latin American literary movement which attempts to depict the reality in human's mind. This literary movement is originated in the Latin American's fiction in the middle of twentieth century. Isabel Allende, who is famous because in the most of her novels the magic realism is used, depicts the life of Ines Suarez, without whom the settlement of Chile could not be achieved, in the historical novel "Ines of my soul".

The father of magic realist writers, Gabriel Garcia Marquez in "Love in the time of cholera", depicts the inside and outside worlds of man in this world, with the using of magic realism, he wants to show these opposites clearly.

In this study, firstly, a model of analysis will be assumed by the features of magic realism. Next, Allende's and Marquez's novels will be read and analyzed within the magic realism pattern, the magic realism's features will be traced in the novel. Finally, possible implications of both the model and the findings of the research for literary criticism and teaching novels of this kind will be discussed.
\end{abstract}

Keywords: Magic Realism, Latin American Literature, Fiction, Isabel Allende, Gabriel Garcia Marquez, literature, 20th century

\section{Introduction}

This research examines establishing a pattern for literary analysis by some features of magic realism and tries to show Isabel Allende's "Ines of my soul" and Marquez's "Love in the time of Cholera" within this framework.

The term magic realism was used for the first time by literary critic Franz Roh in Germany. He regarded magic realism, as a special part of art in literature. For Roh magic realism was the strange describe of reality, and the way of manifestation which replies to state of being real (Bowers, 2004).

One of the literary motions which concentrated on the imaginary elements of human's life is magic realism. Also, it found in fantastical residence located initially in Latin America. During the 1920s and 1930s in Europe, its particular effects are established in the surrealist movement. Therefore, it was placed in Europe, specifically France and Germany, where the two great critics of surrealism were Andre Berton and Franz Roh correspondingly (Zamora \& Faris, 1955).

For manifestation of America's believing and making a recent way of contemporary literature magic realism was the ability in Latin America in 1940 (Spindler, 1993).

The famous author of Latin America, Isabel Allende is well-known writer because of using magic realism in her works. She was born in 1942 in Peru. "The House of Spirit" was published in 1982 as her first novel, and won sum of awards in France, Germany, Mexico and Belgium. Chile and its citizen are the major theme in Allende's novels. "Ines of my soul" one of her best seller novel in 2006.

Marquez was born in 1928 in Colombia, as a prominent writer of South America. In 1967, he published his most famous novel "one Hundred years of solitude". One of his prize was for "Love in the time of Cholera". 
It is prominent to examine Marquez and Allende effect on the Latin American authors. Moreover, it is beneficial to observe Allende and Marquez novels. Because of the influences that Allende and Marquez have got on other Latin American writers and even some American Writers, their works are worthwhile to be seen and analysed within the framework of magic realism. As such, this present research attempts to read "Ines of my soul" and "Love in the time of Cholera" with this guideline from a comparative perspective (main, 2009). The aim is discover the extent to which these writers have used features of magic realism in their novels.

\section{Discussion and Analysis}

\subsection{Magic Realism}

Magic Realism was employed in Roh's essay to depict a new partiality in the art of that time. Since, the essay was converted into Spanish, this literary movement understood by South American authors and critics in 1940s (Roh, 1968).

Following the 1980s, magic realism extended to outside region of the western world, with Africa and also Indian authors. But its united with the geographical territory of Latin America (Schmit, 2010). Therefore, the Nobel Prize winning Marquez, Allende, Carpentier, adapt the mode because of their way of new using of this technique and have fortified the relation among Latin American literature and magic realism (Ziegler, 2008). However, understanding both the nature and term of this literary movement by discovering the magic realism's features can be more possible. So, based on the table 1, there are many elements which depicts as features and also principles of magic realism. There for, the models of analysis will be shaped for discussing the novels. In addition, with using the features of magic realism the novel of this type can be more comprehend (Rafati, 2017).

Table 1. Features and principles of magic realism

\begin{tabular}{|c|c|}
\hline Features of Magic Realism & Principles of Magic Realism \\
\hline \multicolumn{2}{|c|}{$\begin{array}{l}\text { 1. Narrative technique that blurs the distinction of fantasy and reality in } 1 \text {. Supernatural events appear in the story. } \\
\text { the story. }\end{array}$} \\
\hline 2. Metaphors are hyperbolic and ironic in the story. & $\begin{array}{l}\text { 2. Normalising and naturalising, these as the non-realistic elements in the } \\
\text { story. }\end{array}$ \\
\hline \multicolumn{2}{|c|}{$\begin{array}{l}\text { 3. Malice; gives the narrative an illusion that it is either comic or } 3 \text {. Marvelous fiction is the component of the magic realistics story. } \\
\text { bloodcurdling. }\end{array}$} \\
\hline 4. Fable and Myth are presented in the story. & 4. The traditional way of Latin America, is in the story. \\
\hline \multicolumn{2}{|c|}{$\begin{array}{l}\text { 5. Montage technique; the name and description of a country and other } 5 \text {. Superstition, that is the main part of magic realistics story. } \\
\text { details taken from real life. }\end{array}$} \\
\hline 6. The elements of tragedy (Death, Fate,...) are structured the story. & $\begin{array}{l}\text { 6. Binary opposition (the realistic and the magical) can be discovered in } \\
\text { the story. }\end{array}$ \\
\hline $\begin{array}{l}\text { 7. Metamorphosis where a person or object goes into a new being but } \\
\text { narrator treats that it is normal events. }\end{array}$ & 7. History blended with the magical events in the story. \\
\hline
\end{tabular}

\subsection{Magical Realism Features}

Magic Realism proposes a complex fiction which combines metropolis believing refuse some constituent of it and unified the indigenous traditional cultures too. Such a myth, it supplies the way of summarizing the reality mainly. It was strongly established in everyday reality and declared human being's amazement before the marvels of the factual world, and carries a sight of the imaginary features of factuality. Magic Realism is a type of current times fiction, that is marvelous and imaginary occurrence are contained in a narrative which besides sustains the 'reliable' tone of impartial realistic inform. Designating an inclination of the contemporary novel to obtain beyond the limits of realism and draw upon the power of folk tale, fable and myth during preserving a powerful current social relatedness. In such novels the fantastic ascribes granted to characters flight, levitation, telepathy, and telekinesis, so it means that magic realism adopts to enclose the phantasmagoric political actualities of 20th century (Zamora \& Fraris, 1955).

Malice, that bestows the narrative false impression of reality that one is comic and the other is bloodcurdling. The episodes of the magic realistic story are the same as fable with morals. Magic Realism utilizes the fables to intensify the moral estimates of the manuscript (Galnes, 2002).

The another feature of magic realism is Montage technique, in which the identity and explanation of a country and other descriptions are seized from the actual life. The country borrowed its name from the other countries or the world of imagination. So, it such an actual country and it begins the fantasy one (Galnes, 2002). 
Tragedy is another feature of magic realism which consists of two components; Death and Fate, in which borrowed in the magic realist fiction as follows:

The stories are subjected to fate, the heroes are always characterized by their deeds, author utilizes irony to emphasize death's value, the ending is sometimes catastrophic.

Metamorphosis is an occurrence in magic realistic fictions, where human or things converts to new start. Most of the characters are archetypes which reveals confront between modernity and universe. Therefore, it is mixed of real setting and magical characteristics (Zamora \& Frais, 1955).

\section{Application and Analysis}

Based on magic realism's features as a way of writing and literary movement which discussed above, the novels which connect to magic realism can be analyzed. In this study, Allende "Ines of my soul" and Marquez "Love in the time of Cholera" was selected to be read and analyzed based on the features of magic realism.

\subsection{The Analysis of "Ines of My Soul" Based on the Features of Magic Realism}

Ines Suarez, who suffered from the destiny, seeking for her lost husband in New World, but she became one of the main people for conquering of the Chile. When she found her romance with Pedro de Valdivia, the new city of Santiago was built by these lovers. Unfortunately, the cruel world took apart them from each other.

Ines Suarez's life narrates by Ines who depicts a clear picture of her life in her diary. In chapter one Ines begins her story:

"I am Ines Suarez, a townswoman of the loyal city of Santiago de Nueva Extremadura in the year of our Lord 1580" (chapter 1, p. 1).

In Latin American literature fable and myth are the ways of writing fiction are used as a magic realism feature in the story. Allende uses this feature for describing Eldorado the city of gold:

"El Dorado, a city of pure gold, where children's play toys were topazes and emeralds" (chapter1, p. 14).

Allende is well-known for using the Montage technique in which comes from the real names. She depicts a Chile's region as follows:

"Started out for Chile, a still unexplored region whose name in Aymara means Where the land ends" (chapter 2, p. 62).

The components of Tragedy such as death, fate, and etc, are organized the novel. Ines hears Valdivia's voice during dying:

"I clearly heard Pedro de Valdivia's screams, and his voice telling me good-bye for the last time. Farewell, Ines of my soul..." (chapter 6, p. 313).

\subsection{The Analysis of "Love in the Time of Cholera" Based on the Features of Magic Realism}

The story is about two lovers; Florentino Ariza and Fermina Daza. Fermina marries to a wealthy doctor and Florentino leaves the city, trying to start his business but his heat still is beating for Fermina. After Fifty years destiny calls them for new beginning with each other.

Essentially, in magic realism novels, the narrative technique is structured the whole of the story. Marquez uses it in the first chapter of his novel:

"The other windows, as well as every other chink in the room, were muffled with rags or sealed with black cardboard, which increased the oppressive heaviness"(chapter 1, p. 1).

Fable and Myth which narrates for constructing the story be more magical, here is used like this:

"Conscious of the fatality of love, he had often wondered how the meeting would be that he was bound to have with Lorenzo Daza sooner or later" (chapter 2, p. 80).

Using Metaphor in which utilizes in magic realism is depicted in the story:

"His lips were as blue as the corpse and he could not stop the trembling of his fingers as he refolded the letter and placed it in his vest pocket"(chapter 1, p. 7).

Marquez uses Montage technique to illustrate the world of reality in his magic novel:

"He was her only child, born of an occasional alliance with the well-known shipowner Don Pius V Loayza, one of the three brothers who had founded the River company of the Caribbean and thereby given new impetus to steam navigation along the Magdalena River" (chapter 2, p. 53). 
The element of Tragedy (fate, death,...) is used in the story for depicting the magic realism as well:

"There was enough light for him to recognize at once the authority of death" (chapter 1, p. 1).

\section{Conclusion}

To sum up, magic realism is a well-known revolution in literature in Latin America that has some characteristics for examining and clarifying the literary acts. Similarly, it is mentioned in these two novels the magic realism's features like; Tragedy, Montage technique, Fable and Myth, Malice, Narrative technique; which can be examined the works like these.

Magic Realism is a part of literature, dominant form in late-twentieth-century fiction worldwide. It can be used not only in two these novels of Allende and Marquez, but to others too. Also, the works of other authors in all parts of the world like Toni Morrison, Borges and others can be observed in this case study. So, this model of analysis will be utilized for more studies of literary criticism.

\section{References}

Bowers, M. A. (2004). Magical Realism. New York: Rutledge.

Flora, A. (1955). Magical Realism in Spanish American fiction. Hispania, 38(2), 187-220.

Galnes, D. (2002). Literary Movement (vol. 2). New York: Gale group print.

Main, M. (2009). Isabel Allende award wining Latin American author. Retrieved from http/Amazon.com

Rafati, A. (2017). Ines of My Soul from the View Point of Magic Realism. Iran: Arena.

Roh, F. (1968). Nnach-expressionismus magischer realismus: Probleme de neuster europaischen malerie. Kilinkhardt and Biermann, Leipzing.

Schmit, Sh. T. (2010). Magic realism as a genre. Retrieved from http/www.Amazon.com

Spindler, W. (1993). Magic realism: a typology for modern language studies, Xxxix(1), 75-89.

Zamora, L., \& Faris, W. (1955). Magical Realism: Theory, History, Community. Duke: Duke University press.

Ziegler, R. M. (2008). Characteristics of magical realism genre of literature. Retrieved from http/helium.com

\section{Copyrights}

Copyright for this article is retained by the author(s), with first publication rights granted to the journal.

This is an open-access article distributed under the terms and conditions of the Creative Commons Attribution license (http://creativecommons.org/licenses/by/4.0/). 